\title{
THE INFLUENCE OF LEARNING ORGANIZATION AND ORGANIZATIONAL STRESS ON PERFORMANCE OF CREATIVE INDUSTRY SMES WITH THE CREATIVITY OF ITS OWNERSIACTORS AS MEDIATOR
}

\author{
Herawati Yusleli*, Lupikawati Marieska, Purwati Elisa \\ Sriwijaya State Polytechnic, Indonesia \\ ${ }^{*}$ E-mail: leli kosim@yahoo.com
}

\begin{abstract}
The purpose of this study was to determine the influence of organizational learning and organizational stress on the performance of creative industry SMEs with the creativity of its owners/actors as mediator. Type of data used in this research was primary data, namely in the form of questionnaires and partly done also with interviews directly. Data analysis technique used was path analysis method. The population of this research was the owners of SMEs located in Palembang City under the guidance of the Ministry of Cooperatives and SMEs of South Sumatra Province based on data of 2016, which is classified as creative industry SMEs in the area of Palembang City as much as 65 SMEs. The sampling technique was census method. Based on that number, the returned questionnaires only 63 questionnaires from 65 questionnaires distributed. The results of research stated: first hypothesis is accepted where there is influence of learning organization on creativity of SMEs actors, with the influence of $0.705(70.5 \%)$; second hypothesis is rejected, there is no influence of organizational stress on creativity of SMEs owners. Third hypothesis is accepted, where there is influence of learning organization on performance of creative industry SMEs, with the influence of $0.229(22.9 \%)$. Fourth hypothesis is accepted, there is influence of organizational stress on performance of creative industry SMEs, with the influence of $0.229(22.9 \%)$. Fifth hypothesis is accepted, where there is influence of creativity of SMEs owners on performance of creative industry SMEs, with the influence of $0.254(25.4 \%)$. Sixth hypothesis is accepted, where there is influence of learning organization on performance of creative industry SMEs through creativity of SMEs owners as mediator variable with total effects of 0.589 or $58.9 \%$. Seventh hypothesis is accepted, where is influence of organizational stress on performance of creative industry SMEs through creativity of SMEs owners as mediator variable, with total effects of 0.219 or $21.9 \%$.
\end{abstract}

\section{KEY WORDS}

Learning organization, organizational stress, creativity, creative industry.

People are getting familiar with the home industry that sells creative ideas in generating revenue. Economists call it the "creative economy". The creative economy is one of the most important sectors that support the development of the national economy that contributes to the average gross domestic income of 7.8 percent per annum and employing an estimated 7.4 million people. From 2004 to 2010 creative industry exports increased by an average annual growth of 12 percent and recorded a value of 131 trillion rupiahs in 2010, and it is expected that by 2025 the creative industry accounts for 11 percent of GDP and 12-13 percent for exports (Executive Summary, 2006).

The growth of the creative industry still needs the support of various parties, so it has a great contribution to economic development. The problems faced today are the weak capability of human resources, especially creativity and innovation capabilities, thus impacting on the weakness of competitive advantage and business performance. The creative economy is the seventh most important sector of the ten national economic sectors. The creative economic contribution to the gross domestic product (GDP) in 2011 is able to create the added value of Rp 256 trillion and in 2012 is estimated to reach Rp 573.4 trillion. While the number of workers absorbed in the creative economy in 2011 reached 11.51 million people and in 2012 would increase to 11.57 million people. The number of businesses 
in the creative economy sector in 2010 reached 5.5 million, where the handicraft sector reached $20.3 \%$ or 1.07 million, fashion of $20.1 \%$ or 1.06 million and the largest was dominated by the culinary sector which is $56.5 \%$ or 2.797 million (Ministry of Industry and Trade, 2008).

Creativity and innovation of creative industry actors are needed to grow and compete, therefore creative business actors must be able to change the paradigm of culture in the context of performance-based art into performance-based entrepreneurship. Likewise, business actors are expected to turn their profit-oriented life culture into customer-oriented in order to establish a profitable cooperation in the long term. Creative industry actor is a good individual who has the ability to take the challenge, competitive, strategic and has a strong desire for business achievement (Halim, 2011).

The demand to advance SMEs, often make the owners/actors in SMEs feel burdened due to lack of supporting facilities that greatly hamper the operational activities of SMEs. Conditions in which SMEs are always required to contribute ideas and creativity for business progress because of competition and efforts to maintain business continuity leads to stress. While on the other hand, SMEs actors are required to create their business into learning organizations. Where all the elements in the business become proactive to increase selfdesire, keep trying and keep learning by creating an open organizational climate and clear information flow. This condition will lead to a continuous process with reference to internal conditions of the organization that ultimately refers to external conditions and demands from outside of the organization.

Research conducted by Febrianty and Divianto (2017), the purpose of the research was to know the influence of entrepreneurial action group on the performance of SMEs through the role internalization of quadruple-helix innovation (Study on the creative economybased SMEs in Palembang City). The results of the study stated: a. There is a significant influence on Entrepreneurial Action Group to Performance of Creative Economy-Based SMEs, b. There is a significant influence on the Entrepreneurial Action Group on the Role Internalization of Creative Economy-Based Quadruple Helix Innovation, c. There is no influence on the Role Internalization of Quadruple Helix Innovation on the performance of Creative Economy-based SMEs, d. There is significant influence on Entrepreneurial Action Group and Role Internalization of Quadruple Helix Innovation on the performance of Creative Economy-Based SMEs. Other research by Mulyana and Sutapa (2014) on Enhancement of Innovation Capabilities, Competitive Advantage and Performance through Quadruple Helix Approach: Study on the Creative Industry of the Fashion Sector. The results showed quadruple helix (intellectuals, government, business, civil society) have a significant effect on creativity. Intellectuals and business have a significant effect on innovation capability, but the government and civil society have no significant effect on innovation capability. Creativity has a significant effect on innovation capability. Creativity and innovation capabilities have a significant effect on competitive advantage and performance. Research on Increasing Competitiveness of SMEs Based on Innovation and Creativity (Strategy of Property Right Strengthening on Innovation and Creativity), by Darwanto (2013). This purpose of this study was to formulate an institutional strategy in encouraging innovation and creativity of SMEs actors with SWOT analysis method. This study also made comparative strategies to create strong institutions for the creation of creativity and art that can improve the competitiveness of SMEs from several countries. Problems of SMEs related to productivity include lack of property right protection over innovation and creativity. This results in the frequent occurrence of plagiarism in a product that is detrimental to the SMEs of product creators. The property right on the product or product design does not serve as a production incentive. The neglected property right creates a production disincentive. Therefore, there need to be incentives for the creators of production so that they remain driven innovation and creativity continuously. Steps that can be done is an appreciation through the granting of patents to SMEs that are innovative. This will encourage further creations and produce products with features and designs that attract consumers.

Therefore, the authors interested in examining the influence of learning organization and organizational stress on the performance of SMEs creative industries in Palembang City 
with the creativity of the SMEs owners/actors as a mediator. The higher the level of creativity of the SMEs owners/actors in a city then the city can be called Creative City. Creative City means the city where government and society have creative ideas and supported by aspirational public policy in order to develop the potency and competitiveness of the region. The purpose of this study was to determine the influence of learning organization and organizational stress on the performance of SMEs creative industry with the creativity of SMEs owners/actors as a mediator.

\section{LITERATURE REVIEW}

\section{Creative Industry}

Claire (2009) wrote about how to grow creative economics in Tacoma, USA using an experiment called "Tacoma Experiment". This experiment recruited 30 people with professional backgrounds from various fields to work for a year. The process of the experimental project showed how the 30 people were keeping each other in communication so as to create a good relationship with each other. The core of the research is the exchange of ideas and information between individuals can increase the value of someone's creativity. The value of someone's creativity is believed to increase the communication. The research is enough to provide an overview of the development of creative economy.

The era of globalization has an impact on the shift in the paradigm of industry, from the era of industrialization to the information age and lately the era of the creative economy. The creative industry focuses on the creation of goods and services by relying on expertise, talent and creativity as intellectual property that will be able to encourage increased incomes. Creative industry is defined as an industry derived from the utilization of creativity, skills and individual talents to create welfare and employment through the creation and utilization of the creative power and creativity of the individual. There are 14 creative industry subsectors: advertising, architecture, art, craft, design, fashion, video/film/photography, interactive games, music, performing arts, publishing and printing, computer software, television and radio services, research and development (Ministry of Industry and Trade, 2008).

Definition of MSMEs. Law Number 20 of 2008 on Micro, Small and Medium Enterprises (MSMEs) defines MSMEs based on certain criteria, namely:

- Micro Enterprise is productive business owned by individual and/or individual business entity which meets the criteria of Micro Business as regulated in this Law.

- Small enterprise is a stand-alone productive economic enterprise undertaken by an individual or a business entity that is not a subsidiary or not a branch of a company which owned, controlled or constituted either directly or indirectly by a medium-sized or large-scale business that meets the criteria of a small business in this Law.

- Medium enterprise is a stand-alone productive economic enterprise, carried out by an individual or business entity which is not a subsidiary or a branch of a company that owned, controlled or otherwise part of either directly or indirectly by a small or large enterprise with net worth or annual gross sales as stipulated in this Law. The criteria of MSMEs by total assets and turnover in accordance with Law Number 20 of 2008:

Table 1 - The criteria of MSMEs by total assets and turnover

\begin{tabular}{|c|c|c|}
\hline \multirow{2}{*}{ Description } & \multicolumn{2}{|c|}{ Criteria } \\
\cline { 2 - 3 } & Assets & Turnover \\
\hline Micro Enterprise & Maximum of 50 million & Maximum of 300 million \\
\hline Small Enterprise & More than $50-500$ million & More than 300 million-2.5 billion \\
\hline Medium Enterprise & More than 500 million-10 billion & More than 2.5 billion-50 billion \\
\hline
\end{tabular}

Source: Law Number 20 of 2008.

Creative Industry. Creative industry is defined as an industry derived from the utilization of creativity, skills and individual talents to create prosperity and employment by generating and empowering the creative power of the individual (Ministry of Industry and Trade, 2007). The creative industry cited in Saksono (2012) is part of the creative economy, where the 
creative economy is a system of transactions (supply and demand) which has a broader understanding than the creative industry. United Nations Conference on Trade and Development (UNCTAD) in "Creative Economy Report 2010" (2010) defined creative economy as "The "creative economy" is an evolving concept based on creative assets potentially generating economic growth and development. It can foster income generation, job creation and export earnings while promoting social inclusion, cultural diversity and human development. It embraces economic, cultural and social aspects interacting with technology, intellectual property and tourism objectives. It is a set of knowledge based economic activities with a development dimension and cross-cutting linkages at macro and micro levels to the overall economy. It is a feasible development option calling for innovative, multidisciplinary policy responses and interministerial action. At the heart of the creative economy are the creative industries."

The Government of Indonesia officially launched the Creative Economy Program (Presidential Instruction Number 6 of 2009 on Creative Economy Development) which must be implemented by several ministries/agencies and all local governments (provinces and regencies/municipalities). The President also proclaimed 2009 as "Tahun Indonesia Kreatif". However, paying attention to the various limitations, the Government set the priority of the creative economy development in the period of 2009 - 2014 focused on 7 (seven) creative industry groups, namely: 1. architecture; 2. fashion; 3. crafts; 4 . computer and software services; 5 . advertising; 6 . interactive games; and 7. research and development.

The Creative Industry Map in Indonesia's Economy Year 2020 (Data Global Business Guide Indonesia - 2011) shows the contribution of the creative industry in the domestic economy (http://www.gbgindonesia.com). The absorption amount of human resources reaching \pm 7.5 million workers in the sub-sector of creative industry indicates the potential of the country's youngsters creative talent. Latuconsina (2010) stated that creative human resource is a prerequisite for filling a role in the creative industry. The creative industry is the way to build a creative economy or knowledge-based economy.

The scope of the creative economy activities can cover many aspects. Ministry of Industry and Trade (2008) identified at least 14 sectors included in the creative economy:

Table 2 - Sub-sectors of Creative Economy in Indonesia

\begin{tabular}{|c|l|l|}
\hline No & \multicolumn{1}{|c|}{ Sectors } & \multicolumn{1}{c|}{ Sub-sectors } \\
\hline 1 & Advertising & Process of creation, production, and distribution \\
\hline 2 & Architecture & Building design, construction supervision, urban planning \\
\hline 3 & Market of Art Goods & Unique and rare goods that have aesthetic art value \\
\hline 4 & Crafts & $\begin{array}{l}\text { Precious stones, natural and artificial fibers, leather, rattan, bamboo, wood, metal, } \\
\text { glass, porcelain, fabrics, marble, clay, and lime }\end{array}$ \\
\hline 5 & Design & Graphic design, interior design, product design, dan industry design \\
\hline 6 & Fashion & Creation of clothing design, footwear design, and other fashion accessories design \\
\hline 7 & $\begin{array}{l}\text { Video, Film, and } \\
\text { Photography }\end{array}$ & $\begin{array}{l}\text { Production of video, film and photography services as well as distribution of video } \\
\text { recordings, films and photographic results }\end{array}$ \\
\hline 8 & Interactive Games & Video and computer games that have entertainment, agility, and education values \\
\hline 9 & Music & $\begin{array}{l}\text { Distribution, reproduction of recording media, representation-promotion } \\
\text { management (agency) music, composer services, songwriting services and singing } \\
\text { services }\end{array}$ \\
\hline 10 & $\begin{array}{l}\text { Performing Arts } \\
\text { Content development, show production, ballet shows, traditional dance, } \\
\text { contemporary dance, drama, traditional music, theater music, and other performing } \\
\text { arts }\end{array}$ \\
\hline 11 & $\begin{array}{l}\text { Publishing and } \\
\text { Printing }\end{array}$ & $\begin{array}{l}\text { Computer and } \\
\text { tabloids, and digital content as well as news agency activities }\end{array}$ \\
\hline
\end{tabular}

Organizational Stress. The word "stress" comes from the Latin, Stingere, used in the XVII century to describe hardship, suffering, and misfortune. In a chance Smith in Tunjungsari (2011) argued that the concept of work stress can be viewed from several angles: first, work stress as the result of the workplace situation. Second, work stress as the result of two organizational factors namely involvement in tasks and organizational support. 
Third, stress due to workload. Fourth, the result of excessive work time. Fifth, the work responsibility factor.

Kahn and Quin (in Ivanceviech et al, cited in Dhania, 2010), added that work stress is a negative work environment, one of which is excessive workload at work. The same thing was also expressed by Keenan and Newton in Dhania (2010) stated that work stress is a manifestation of the blur of roles and excessive workload.

Stress is an internal condition that occurs with physical disturbances, environmental, and social situations that have potency in conditions that are not good. This opinion was expressed by Morgan \& King (1986) quoted in Dhania (2010). "The feelings of distress experienced by employees in the face of work. This work stress is visible from the symptom, including unstable emotions, uneasy feelings, aloofness, sleeplessness, excessive smoking, can not relax, anxiety, tension, nervousness, increased blood pressure, and indigestion "(Mangkunegara, 2008 ). "Conditions which arise from the interaction between human beings and work characterized by human changes that compel them to deviate from their normal function." (Robbins, 2006).

The results of research by Kuan (1994), Bat (1995), Aun (1998) and Yahya (1998) cited in Dhania (2010) proved that excessive workload affects work stress. Furthermore, the research of Widjaja (2006) found that workloads that are too difficult to work and technologies that do not support to do the job well become a source of stress for employees.

Quick and Quick (1984) cited in Dhania (2010), categorized the types of stress into two, namely: Eustress, which results from a response to stress that is healthy, positive, and constructive, and the second Distress, which results from a response to stress that is unhealthy, negative, and destructive. Stress is an adaptive response to external situations that result in physical, psychological, and/or behavioral deviations in organizational members. The conclusion above shows the existence of certain conditions in the environment which is a potential source for the emergence of stress. How the shape of the stress depends on the unique characteristics of the individual concerned and appreciation of the potential environmental factors creates stress on it, even though almost every group of people are exposed to similar types of stress conditions, but this will result in different reactions, even in the face of the same type of stress or condition, each individual can vary the reaction pattern.

Influencing Factors of Organizational Stress. According to Mangkunegara (2008): "The cause of work stress, namely, the workload is too heavy, urgent work time, low-quality work supervision, unhealthy work climate, inadequate work authority associated with responsibility, work conflicts, value differences between employees and frustrated leaders in work".

According to Handoko in Tunjungsari (2011) revealed that there are a number of working conditions that often cause stress for employees, namely: 1. Excessive workload, 2. Time pressure, 3. Poor quality supervision, 4. Unsafe political climate, 5. Feedback on inadequate implementation of work, 6 . The ambiguity of roles, 7. Frustration, 8. Interpersonal and intergroup conflicts, 9. Differences between corporate and employees values 10. Different forms of enterprise.

Work Stress Approach. According to Rivai (cited in Tunjungsari, 2011) work stress approaches can be done by:

- Individual approaches: a. Increase faith, b. Do meditation and breath, c. Do sports activities, d. Relax, e. Social support from friends and family, f. Avoid the boring routine.

- The company approaches: a. Improve organizational climate, b. Make improvements to the physical environment, c. Provide sports facilities, d. Conduct analysis and clarity of duties, e. Increase participation in decision-making process, f. Perform task restructuring, g. Apply the Goal-Based Management concept.

Learning Organization. Senge (1990) in Tobing and Fitriati (2009) said that learning organization is the organization where people continually expand their capacity to create the results they really want, where new patterns and thinking expansion are nurtured, in which collective aspirations are liberated, and where people are constantly learning to see together 
thoroughly. Furthermore, Senge also said that the requirements of an organization into a learning organization that every individual who wants to compete in the business environment should make the organization as a "learning organization", by constantly adapting to the environment. Senge offered five disciplines known as "five new component technologies", which is believed to be the "discipline" that every organization needs to become the foundation for building successful learning organization to face and create changes.

Meanwhile, according to Marquardt (1996) cited in Tobing and Fitriati (2009), there are six skills an organization must possess to become a learning organization, the first five skills are the five disciplines of learning organization proposed by Senge, and supplemented by the sixth skill, that is dialogue. Dialogue is the ability to learn, hear and communicate with fellow members of the organization. In a company that has become a learning organization, skills are manifested by: the attitude of company members to be open, willing to listen, to discuss, give suggestions or criticism, and exchange ideas in conducting learning process and continuous improvement in the company.

Characteristics of Learning Organization. The learning organization has five main characteristics known as the five disciplines that are expected to bring the business organization into an innovative organization (Senge, 1990 cited in Dwiprabowo, Mulyaningrum, and Suwarno, 2013), namely: a. The organization basically consists of units that must work together to produce optimal performance, b. Personal Mastery, c. Mental Model, d. Shared Vision, and e. Team Learning.

Creativity. According to Hadiyati (2011), creativity is the initiative of a product or process that is useful, correct, appropriate, and valuable to a heuristic task that is an incomplete guide or guide that will guide us to understand, study or find something new. Suryana (2003) stated that creativity is: "Thinking something new". "Creativity as the ability to develop new ideas and to discover new ways of solving problems in the face of opportunities". Creativity is the ability to develop new ideas and discover new ways of looking at problems and opportunities whereas innovation is the ability to find creative solutions to problems and opportunities to enhance or enrich life (Zimmerer, 2008). Collaborative creativity is a prerequisite for innovation generation (Gerald, 2009).

A. Roe in Frinces (2004) stated that requirements of creative person are: a. openness to experience. b. observanvce seeing things in unusual ways, c. Curiosity/tolerance of apporites, $\mathrm{d}$. independence in judgement, thought and action, e. needing and assuming autonomy, f. self-reliance, $g$. not being subject to group standart and control, $h$. willing to take calculated risks.

Business/SMEs Performance. Voss and Voss (2000) stated that business performance is defined as a measure of performance levels including sales turnover, number of buyers, profits and sales growth. Organizational performance or often referred to as business or company performance is an indicator of success rate in achieving company goals. Good corporate performance demonstrates the success and efficiency of corporate behavior. Many studies use different indicators to measure business performance. To measure business performance, it is usually done using profitability indicators over the past three years. Agarwal et al. (2003) measured business performance using two dimensions: the first dimension is financial performance or performance based on marketing such as usage level, profitability and market share, while the second dimension is subjective performance. Subjective performance is a performance measurement based on customer and employee satisfaction, such as service quality, customer satisfaction, and employee performance satisfaction.

\section{METHODS OF RESEARCH}

Research Design. The research design is a causal research. The research framework is presented in Figure 1.

Type and Sources of Data. Type of data used in this research was primary data, namely in the form of questionnaires and partly done also with interviews directly. 


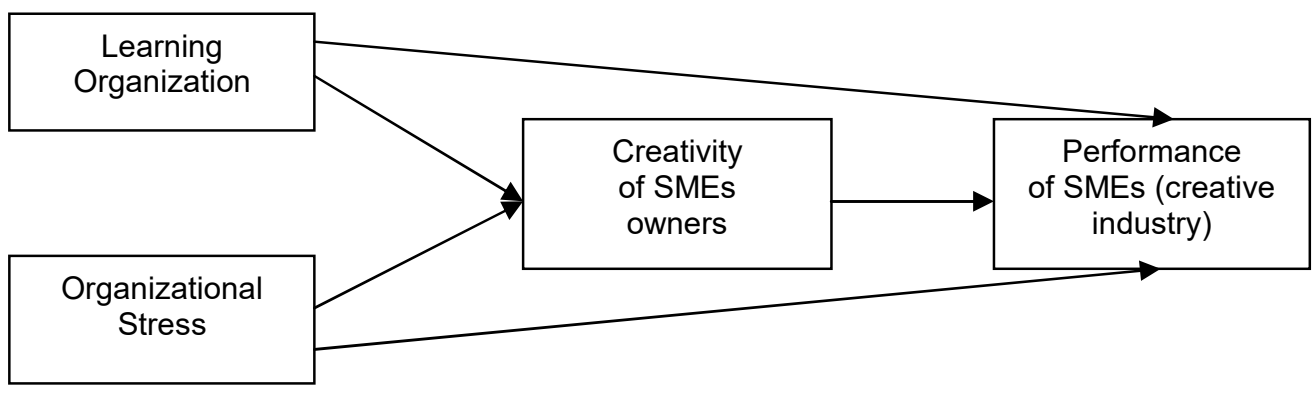

Figure 1 - Research Framework

Research Sample and Population. The population of this research was the owners of SMEs located in Palembang City under the guidance of the Ministry of Cooperatives and SMEs of South Sumatra Province based on data of 2016, which is classified as creative industry SMEs in the area of Palembang City as much as 65 SMEs. The reason for the selection of creative industry SMEs is creative industry SMEs absorb the most labor force compared to other sectors. The sampling technique was census method.

Research Variables Operationnal Definitions:

Table 3 - Variables Operational Matrices

\begin{tabular}{|c|c|c|c|c|}
\hline Variable & Definition & Indicators & $\begin{array}{c}\text { Number of } \\
\text { Questions in } \\
\text { Questionnarie }\end{array}$ & Scale \\
\hline $\begin{array}{l}\text { Learning } \\
\text { Organization }\end{array}$ & $\begin{array}{l}\text { Organizations in which people } \\
\text { continually expand their capacity to } \\
\text { create the results they really want, } \\
\text { where new patterns and thinking } \\
\text { expansion are nurtured, in which } \\
\text { collective aspirations are liberated, } \\
\text { and where people continually learn to } \\
\text { see together thoroughly (Senge 1990, } \\
\text { in Tobing and Fitriati (2009) So it is a } \\
\text { process to improve action through } \\
\text { better knowledge and understanding. }\end{array}$ & $\begin{array}{l}\text { Learning method } \\
\text { Learning environment } \\
\text { Organizational culture }\end{array}$ & 11 questions & Ordinal \\
\hline $\begin{array}{l}\text { Organizational } \\
\text { Stress }\end{array}$ & $\begin{array}{l}\text { Conditions which arise from the } \\
\text { interaction between human beings } \\
\text { and work characterized by human } \\
\text { changes that compel them to deviate } \\
\text { from their normal function (Robbins, } \\
\text { 2006). }\end{array}$ & $\begin{array}{l}\text { Excessive workload } \\
\text { Pressure } \\
\text { Unsafe political climate } \\
\text { Feedback on inadequate } \\
\text { implementation of work } \\
\text { Frustration } \\
\text { Interpersonal and } \\
\text { intergroup conflicts } \\
\text { Differences between } \\
\text { corporate and employee } \\
\text { values }\end{array}$ & 7 questions & Ordinal \\
\hline $\begin{array}{l}\text { Creativity of } \\
\text { SMEs owners }\end{array}$ & $\begin{array}{l}\text { Creativity is the ability to develop new } \\
\text { ideas and discover new ways of } \\
\text { looking at problems and opportunities } \\
\text { whereas innovation is the ability to } \\
\text { find creative solutions to problems } \\
\text { and opportunities to enhance or } \\
\text { enrich life (Zimmerer, 2008). }\end{array}$ & $\begin{array}{l}\text { Openness to experience } \\
\text { Strong desire } \\
\text { Confidence } \\
\text { Independence in } \\
\text { judgement, thought and } \\
\text { action }\end{array}$ & 4 questions & Ordinal \\
\hline $\begin{array}{l}\text { SMEs } \\
\text { performance }\end{array}$ & $\begin{array}{l}\text { A measure of performance levels } \\
\text { including sales turnover, number of } \\
\text { buyers, profits and sales growth } \\
\text { (Voss and Voss, 2000). }\end{array}$ & $\begin{array}{l}\text { Quantity } \\
\text { Quality } \\
\text { Knowledge } \\
\text { Ability } \\
\text { Skills } \\
\text { Attitude } \\
\text { Interaction }\end{array}$ & 7 questions & Ordinal \\
\hline
\end{tabular}


Data Analysis Technique. Data analysis technique used was path analysis method. Path Analysis was developed by Sewal Wright in 1934. The path analysis for direct effect, indirect effect, and total effect. The structural equations of causality are as follows:

$$
\text { Endogenous variables }=\text { Exogenous variables }+ \text { Endogenous variables }+ \text { Error }
$$

Equation of Sub-structure I:

$$
Y_{1}=a+P X_{1}+P X_{2}+\zeta 1
$$

Equation of Sub-structure II:

$$
Y_{2}=a+P X_{1}+P X_{2}+Y_{1}+\zeta 2
$$

Equation of Sub-structure III:

$$
\begin{aligned}
& Y_{1}=a+P X_{1}+\zeta 1 \\
& Y_{1}=a+P X_{2}+\zeta 1 \\
& Y_{2}=a+P X_{1}+\zeta 2 \\
& Y_{2}=a+P X_{2}+\zeta 2 \\
& Y_{2}=a+P Y_{1}+\zeta 2
\end{aligned}
$$

Where: $X_{1}=$ learning organization; $X_{2}=$ organizational stress; $Y_{1}=$ creativity of SMEs owners; $Y_{2}=$ performance of SMEs (creative industry); $e_{1}=$ Correlation coefficients outside the model; $\mathrm{e}_{2}=$ Correlation coefficients outside the model.

Hypothesis Testing. Hypothesis test in this research was done to statistical hypothesis use $t$ test and $f$ test. Next, present the Coefficient of Determination value.

Research Hypothesis. Research hypotheses are as follows:

- $\mathrm{H} 1$ : there is influence of learning organization on creativity of SMEs owners;

- H2: there is influence of organizational stress on creativity of SMEs owners;

- H3: there is influence of learning organization on performance of creative industry SMEs;

- H4: there is influence of organizational stress on performance of creative industry SMEs;

- H5: there is influence of creativity of SMEs owners on performance of creative industry SMEs;

- H6: there is influence of learning organization on performance of creative industry SMEs through creativity of SMEs owners as mediator variable;

- H7: there is influence of organizational stress on performance of creative industry SMEs through creativity of SMEs owners as mediator variable.

\section{RESULTS AND DISCUSSION}

Description of Respondents. In the research design has been explained that the respondents of this study are the owners of Small and Medium Enterprises located in Palembang city under the guidance of the Ministry of Cooperatives and SMEs of South Sumatra Province based on data of 2016, which belongs to the creative industry SMEs in the area of Palembang City. Based on that number, the returned questionnaires only 63 questionnaires from 65 questionnaires distributed. After the questionnaire ended, the researcher did the editing, coding and data entry for the preparation of data analysis. The results were not all questionnaires can be used as a basis for analysis. The following recapitulation of questionnaire data based on gender and educational background: 
Table 4 - Characteristics of Respondents (SMEs owners/actors) based on gender

\begin{tabular}{|c|c|c|c|c|}
\hline \multirow{2}{*}{ No. } & Creative industry SMEs sector & \multicolumn{2}{|c|}{ Gender } & \multirow{2}{*}{ Total } \\
\cline { 3 - 5 } & & Male & Female & \\
\hline 1 & Fashion & 3 & 11 & 14 \\
\hline 2 & Crafts & 4 & 6 & 10 \\
\hline 3 & Publishing and Printing & 7 & 2 & 9 \\
\hline 4 & Video, Film, and Photography & 11 & 2 & 13 \\
\hline 5 & Culinary & 4 & 13 & 17 \\
\hline & Total & 29 & 34 & 63 \\
\hline
\end{tabular}

Source: Processed primary data, 2017.

Based on Table 4, the percentage of female respondents of creative industry SMEs actors as many as 34 people more than male respondents of creative industry SMEs actors as many as 29 people (53.97\%).

Table 5 - Characteristics of Respondents based on educational background

\begin{tabular}{|c|c|c|c|c|c|}
\hline \multirow{2}{*}{ No. } & \multirow{2}{*}{ Creative industry SMEs sector } & \multicolumn{3}{|c|}{ Last Education } & \multirow{2}{*}{ Total } \\
\cline { 3 - 5 } & Fashion & High School & D3 & S1 & \\
\hline 1 & Crafts & 6 & 7 & 3 & 14 \\
\hline 2 & Publishing and Printing & 4 & 3 & 1 & 10 \\
\hline 3 & Video, Film, and Photography & 6 & 4 & 2 & 9 \\
\hline 4 & Culinary & 6 & 7 & 4 & 13 \\
\hline 5 & Total & 26 & 24 & 13 & 17 \\
\hline \multicolumn{2}{|r|}{}
\end{tabular}

Source: Processed primary data, 2017.

Based on Table 5. the average of creative industry SMEs actors have the educational background with S1 level as many as 13 people, D3 level as many as 24 people, and high school as many as 26 people. This shows that the educational background of creative industry SMEs is still not supporting the improvement of SMEs performance.

Validity and Reliability Test. The two procedures performed in this study measured the consistency and accuracy of data collected from the use of the instrument, namely (1) internal consistency test with Cronbach's Alpha statistical test, (2) correlational test between the score of each item with the total score (Ghozali, 2005). The results of reliability testing resulted in all items or questions are stated as valid. While reliability testing shows the value of Cronbach's alpha is greater than 0.50 so all the variables in this study are stated as reliable.

Classic Assumption Test. The classical assumption tests conducted in this research were multicollinearity, heteroscedasticity and normality test. The results show that the regression results were feasible to use.

Results of Hypothesis Test. Based on the results of linear regression testing and path analysis results for direct effects are presented in Table 6.

Table 7. The following presents indirect effects for learning organization and organizational stress on performance of creative industry SMEs through creativity of SMEs owners as mediator variable.

Table 8. The following presents total effects for learning organization and organizational stress on performance of creative industry SMEs through creativity of SMEs owners as mediator variable.

Influence of Learning Organization on Creativity of SMEs Actors. Based on the results of partial analysis, SMEs actors in Palembang City shows learning organization variable has significant positive value on creativity of SMEs actors with significant value of $<0.5$, with the influence $\left(R^{2}\right)$ of $0.705(70.5 \%)$.

By becoming a learner organization, it will improve the competence and creativity of human resources in SMEs, which of course will produce creative and innovative process and product and able to compete. The more human resources in SMEs continuously do the 
learning process and share knowledge of each and work together in the working group will increase the ability of human resource creativity in creating innovations on the SMEs. This is in line with the research hypothesis that is the influence of learning organization on the creativity of SMEs actors. The result of this studyis in line with Salim and Sulaiman (2011) that learning organization has an effect on innovation ability.

Table 6 - Linear Regression Results and Path Analysis Results for Direct Effects

\begin{tabular}{|c|c|c|c|c|}
\hline Hypothesis & Regression Equation & $\mathrm{F}$ value & $\begin{array}{c}\mathrm{R} \\
\text { square }\end{array}$ & $\begin{array}{c}\text { Hypothesis } \\
\text { Confirmation }\end{array}$ \\
\hline & Equation of Sub-structure III & & & \\
\hline $\mathrm{H} 1$ & $\begin{array}{c}X_{1} \rightarrow Y_{1} \\
Y_{1}=a+P X_{1}+e_{1} \\
Y_{1}=2.700+0.312 X_{1}+e_{1} \\
\text { influence of learning organization on creativity of SMEs } \\
\text { actors }\end{array}$ & $\begin{array}{l}145.675 \\
(0,000)\end{array}$ & 0.705 & Accepted \\
\hline $\mathrm{H} 2$ & $\begin{array}{c}\mathrm{X}_{2} \rightarrow \mathrm{Y}_{1} \\
\mathrm{Y}_{1}=\mathrm{a}+\mathrm{PX}_{2}+\mathrm{e}_{2} \\
\mathrm{Y}_{1}=12.479+0.116 \mathrm{X}_{2}+\mathrm{e}_{2} \\
\text { influence of organizational stress on creativity of SMEs } \\
\text { actors }\end{array}$ & $\begin{array}{c}2.946 \\
(0,091)\end{array}$ & 0.046 & Rejected \\
\hline $\mathrm{H} 3$ & $\begin{array}{c}\mathrm{X}_{1} \rightarrow \mathrm{Y}_{2} \\
\mathrm{Y}_{1}=\mathrm{a}+\mathrm{PX}_{1}+\mathrm{e}_{3} \\
\mathrm{Y}_{1}=14.251+0.314 \mathrm{X}_{3}+\mathrm{e}_{3} \\
\text { influence of learning organization on performance of } \\
\text { creative industry SMEs }\end{array}$ & $\begin{array}{l}18.096 \\
(0,000)\end{array}$ & 0.229 & Accepted \\
\hline $\mathrm{H} 4$ & $\begin{array}{c}\mathrm{X}_{2} \rightarrow \mathrm{Y}_{2} \\
\mathrm{Y}_{1}=\mathrm{a}+\mathrm{PX}_{2}+\mathrm{e}_{4} \\
\mathrm{Y}_{1}=19.778+0.296 \mathrm{X}_{4}+\mathrm{e}_{4} \\
\text { influence of organizational stress on performance of } \\
\text { creative industry SMEs }\end{array}$ & $\begin{array}{c}6.579 \\
(0,013)\end{array}$ & 0.097 & Accepted \\
\hline $\mathrm{H} 5$ & $\begin{array}{c}Y_{1} \rightarrow Y_{2} \\
Y_{2}=a+P Y_{1}+e_{1} \\
Y_{2}=13.317+0.889 X_{1}+e_{1} \\
\text { influence of creativity of SMEs actors on performance } \\
\text { of creative industry SMEs }\end{array}$ & $\begin{array}{l}20.720 \\
(0,000)\end{array}$ & 0.254 & Accepted \\
\hline
\end{tabular}

Table 7 - Linear Regression Results and Path Analysis Results for Indirect Effects

\begin{tabular}{|c|c|}
\hline Hypothesis & Regression Equation \\
\hline $\mathrm{H} 6$ & $\mathrm{X}_{1} \rightarrow \mathrm{Y}_{1} \rightarrow \mathrm{Y}_{2}=(0.312 \times 0.889=0.277)$ \\
\hline $\mathrm{H} 7$ & $\mathrm{X}_{2} \rightarrow \mathrm{Y}_{1} \rightarrow \mathrm{Y}_{2}=(0.116 \times 0.889=0.103)$ \\
\hline
\end{tabular}

Table 8 - Linear Regression Results and Path Analysis Results for Total Effects

\begin{tabular}{|c|c|}
\hline Hypothesis & Regression Equation \\
\hline $\mathrm{H} 6$ & $\mathrm{X}_{1} \rightarrow \mathrm{Y}_{1} \rightarrow \mathrm{Y}_{2}=(0.312+0.277=0,589)$ \\
\hline $\mathrm{H} 7$ & $\mathrm{X}_{2} \rightarrow \mathrm{Y}_{1} \rightarrow \mathrm{Y}_{2}=(0.116+0.103=0,219)$ \\
\hline
\end{tabular}

Influence of Organizational Stress on Creativity of SMEs Actors. Based on the results of partial analysis, SMEs actors in Palembang City shows organizational stress variable does not influence the creativity of SMEs actors with significant value of $>0.5$. Thus, the second hypothesis in the study that states that there is an effect of organizational stress on the creativity of SMEs, rejected.

The effect of organizational stress is not necessarily negative or in other words, organizational stress can have a beneficial impact on the creative industry SMEs. The stress level of a particular organization stress is expected to spur the SMEs workers to be able to complete the job as well as possible. Workers or those in stress conditions will show behavioral changes. These changes occur as a form of effort to cope with the stress experienced. Although the actual appreciation on the factors of the environment that potentially bring stress to him, how to deal with or control of stress, the reaction to stress experienced, all depends on the individual concerned. Therefore it does not mean a similar 
type or condition of stress, will cause the same reaction. The results of this study do not support the findings of previous studies conducted by Sabrina (2017), which partially proved that there is a negative and significant relationship between work stress on work achievement in TVRI Kaltim Station.

Influence of Learning Organization on Performance of Creative Industry SMEs. Based on the results of partial analysis, SMEs actors in Palembang City shows learning organization variable has significant positive value on performance of creative industry SMEs with significant value of $<0.5$, with the influence $\left(R^{2}\right)$ of $0.229(22.9 \%)$. This influence can be enhanced, of course, with the role of learning groups creation and ongoing learning processes by both SMEs owners and employees. Workers in SMEs participate in the implementation of SMEs vision, evaluate work, and adapt the better production methods and apply product quality standards within SMEs in order to improve product quality so as to increase knowledge, skills and creativity of human resources in SMEs in creating innovation and performance improvement of SMEs in Palembang City.

The result of this study is in accordance with previous research conducted by Power and Waddell (2004) and Sampe (2012) which stated that learning organization has a significant relationship with the performance of SMEs. This is also in line with statements from Ellitan and Anatan (2009) that learning organization reflects that organization learns what needs to learn so that the organization has more performance than its competitors. Individuals in the SMEs who become learning organization will continue to improve their skills by continuing to learn and sharing knowledge with each other about better information and production processes so as to improve the performance of SMEs.

Influence of Organizational Stress on Performance of Creative Industry SMEs. Based on the results of partial analysis, SMEs actors in Palembang City shows organizational stress variable has significant positive value on performance of creative industry SMEs with significant value of $<0.5$, with the influence $\left(R^{2}\right)$ of $0.097(9.7 \%)$.

The results of this study support the research of Sabrina (2017) entitled "The Relationship Between Work Stress And Creativity To Work Achievement on Employees At TVRI Kaltim Station". The research findings showed that no matter how small the dynamics of employee creativity will affect the high and low achievement of work performance. This result was caused by the working world of television stations require employees to have creativity in the form of fresh ideas that are not monotonous.

Influence of SMEs Actors Creativity on Performance of Creative Industry SMEs. Based on the results of partial analysis, SMEs actors in Palembang City shows SMEs actors creativity variable has significant positive value on performance of creative industry SMEs with significant value of $<0.5$, with the influence $\left(R^{2}\right)$ of $0.254(25.4 \%)$.

Creativity related to human resources that exist in SMEs both owners and workers because they are the actors who create creativity in SMEs where SMEs continue the creativity will create a process and production that is modified and completely new so as to improve the performance of SMEs. SMEs that innovate also cannot be separated from the role of human resources to continue to learn in improving their knowledge and skills to produce a process or product that creative and innovative.

The result of this study is also in line with previous research from Salim and Sulaiman (2011) where innovation has a significant effect on improving the performance of SMEs.

Influence of Learning Organization on Performance of Creative Industry SMEs Through Creativity of SMEs Owners as Mediator Variable. Based on the results of partial analysis, SMEs actors in Palembang City shows the creativity of SMEs actors mediate learning organization on performance of creative industry SMEs. Therefore the total effects as 0.589 or $58.9 \%$.

The learning process in SMEs must be related to creativity and innovation where the creative industry SMEs which good in doing knowledge development will be good also in producing/processing innovative/creative products and organizational learning reflects that the organization learn what it needs to learn so that the organization has a performance which is better and able to compete with its competitors. 
Thus, the creativity of SME actors with the support of the creation of learner organizations within the internal scope of SMEs, then SMEs can produce a new product or process both the addition of different features of the products and processes that already exist as well as products and processes that are completely new so as to enhance the competitiveness and characteristics of SMEs so that in Palembang City SMEs are expected ready to compete with other competitors and improve the performance of SMEs.

Influence of Organizational Stress on Performance of Creative Industry SMEs Through Creativity of SMEs Owners as Mediator Variable. Based on the results of partial analysis, SMEs actors in Palembang City shows the creativity of SMEs actors mediate organizational stress on performance of creative industry SMEs. Therefore the total effects as 0,219 or $21.9 \%$.

Excessive work stress will result in the decreasing creativity of creative industry SMEs actors, low-performing workers, insomnia, irritability, uneasiness, increasing errors, nervousness, anxiety, tension, doubts in work that ultimately result in decreased SMEs performance. Conversely, low organizational stress will increase creativity to the performance of creative industry SMEs. So it can be said that creativity is one factor that is very important to get the results of work or optimal performance.

\section{CONCLUSION AND RECOMMENDATIONS}

Based on the discussion that has been done, then conclusions are as follows: First hypothesis is accepted where there is influence of learning organization on creativity of SMEs actors, with the influence $\left(\mathrm{R}^{2}\right)$ of $0.705(70.5 \%)$. Second hypothesis is rejected, there is no influence of organizational stress on creativity of SMEs owners. Third hypothesis is accepted, where there is influence of learning organization on performance of creative industry SMEs, with the influence $\left(\mathrm{R}^{2}\right)$ of $0.229(22.9 \%)$. Fourth hypothesis is accepted, there is influence of organizational stress on performance of creative industry SMEs, with the influence $\left(R^{2}\right)$ of $0.229(22.9 \%)$. Fifth hypothesis is accepted, where there is influence of creativity of SMEs owners on performance of creative industry SMEs, with the influence $\left(R^{2}\right)$ of $0.254(25.4 \%)$. Sixth hypothesis is accepted, where there is influence of learning organization on performance of creative industry SMEs through creativity of SMEs owners as mediator variable with total effects of 0.589 or $58.9 \%$. Seventh hypothesis is accepted, where there is is influence of organizational stress on performance of creative industry SMEs through creativity of SMEs owners as mediator variable, with total effects of 0.219 or $21.9 \%$. Further research should be developed to include ethnic/ethnic variables, Quality of work life, conflict of interest on family SMEs, Perceived Environment Uncertainty, and develop studies on social organization or at Social Worker to see the stress of work/organizational stress.

\section{REFERENCES}

1. Claire, Lynnette. 2009. "Growing a Creative economy-One Experiment". University of Puget Sound. http//www.ssrn.com/abstract=1414371.

2. Darwanto. 2013. Peningkatan Daya Saing UMKM Berbasis Inovasi Dan Kreativitas (Strategi Penguatan Property Right Terhadap Inovasi Dan Kreativitas). Jurnal Bisnis dan Ekonomi (JBE), September 2013, pp. 142 - 149 Vol. 20, No. 2 ISSN: 1412-3126.

3. BPS Kota Palembang. 2016. Publikasi Sumatera Selatan Dalam Angka.

4. Data Global Business Guide Indonesia-2011. (http://www.gbgindonesia.com/en/services/ article/2011/indonesia_s_creative_industries.php, accessed on October 25th, 2017).

5. Departemen Perdagangan Republik Indonesia. 2008. Rencana Pengembangan Ekonomi Kreatif Tahun 2009 - 2025.

6. Deperindag. 2008. Subsektor Industri Kreatif di Indonesia.

7. Dhania, Dhini Rama. 2010. Pengaruh Stres Kerja, Beban Kerja terhadap Kepuasan Kerja: Studi Pada Medical Representatif Di Kota Kudus. Jurnal Psikologi Universitas Muria Kudus. Vol.1 No.1 Desember 2010. 
8. Dwiprabowo, Hariyatno, Mulyaningrum, \& Eno Suwarno. 2013. Organisasi Belajar dan Implementasi Kebijakan Hutan Kemasyarakatan (Hkm). JURNAL Penelitian Sosial dan Ekonomi Kehutanan Vol. 10 No. 2 Juni 2013, pp. 85 - 98.

9. Ellitan, L. \& L. Anatan. 2009. Manajemen Inovasi Transformasi Menuju Organisasi Kelas Dunia. Bandung: Alfabeta.

10. Executive Summary. 2006 Hasil Kajian Diputi Bidang Sumber daya Manusia UKM dan Koperasi (http://www.smecda.com).

11. Febrianty \& Divianto. 2017. The Influence Of Entrepreneurial Action Group On The Smes Performance Through Internalization Of Quadruple Helix Innovation Role. Biotika, accessed from https://journal-biotika.com/current-issues/2017-02/article_07.pdf, on October 12th, 2017.

12. Frinces, Heflin. 2004. Kewirausahaan dan Inovasi Bisnis, Cetakan Pertama, Yogyakarta: Penerbit Darusalam.

13. Gerald. S. 2009. The Concept of Open Creativity: Collaborative Creative Problem Solving for Innovation Generation - a Systems Approach. Journal of Business and Management, 15(1), pp. 5-33.

14. Ghozali, Imam. 2005. Aplikasi Analisis Multivariate Dengan Program SPSS. Semarang: Badan Penerbit Universitas Diponegoro.

15. Hadiyati, Ernani. 2011. Kreativitas Dan Inovasi Berpengaruh Terhadap Kewirausahaan Usaha Kecil. Jurnal Manajemen Dan Kewirausahaan, Vol.13, No. 1, pp. 8-16.

16. Halim. A, 2011. The Measurement of Entrepreneurial Personality and Business Performance in Terengganu Creative Industry, Intemational Joumal of Business and Management, Vol. 6, p. 183-188.

17. Instruksi Presiden Nomor 6 Tahun 2009 Tentang Pengembangan Ekonomi Kreatif.

18. Latuconsina, Hudaya. 2010. Kreativitas Tanpa Batas Menuju Ekonomi Kreatif Berbasis Insan Kreatif. Cetakan I. Jakarta: TERAJU.

19. Mangkunegara, A.A. Anwar Prabu. 2008. Manajemen Sumberdaya Manusia Perusahaan Cetakan ke-8, Bandung: Rosda.

20. Mulyana dan Sutapa. 2014. Peningkatan Kapabilitas Inovasi, Keunggulan Bersaing dan Kinerja melalui Pendekatan Quadruple Helix: Studi Pada Industri Kreatif Sektor Fashion. Jurnal Manajemen Teknologi. Vol. 13. No.3.

21. Power, J., and D. Waddell. 2004. The link between self-managed work teams and learning organizations using performance indicators. The Learning Organization11 (3): 244-259.doi:10.1108/09696470410533003.

22. Robbins, Stephen. P. 2006. Perilaku Organisasi (alih bahasa Benjamin Molan), Edisi Bahasa Indonesia, Klaten: PT Intan Sejati.

23. Sabrina, Raissa. 2017. Hubungan Antara Stres Kerja Dan Kreativitas Terhadap Prestasi Kerja pada Karyawan Di Stasiun TVRI Kaltim. Psikoborneo, 2017, 5 (1): 11 - 22 ejournal.psikologi.fisip-unmul.ac.id

24. Saksono, Herie. 2012. Ekonomi Kreatif: Talenta Baru Pemicu Daya Saing Daerah. Jurnal Bina Praja. Volume 4 No. 2 Juni 2012: 93 - 104.

25. Salim, I.M., \& M. Sulaiman. 2011. Organizational learning, innovation and performance: a study of malaysian small and medium sized enterprises. International Journal of Business and Management6 (12).doi:10.5539/ijbm.v6n12p118.

26. Sampe, F. 2012. The influence of organizational learning on performance in Indonesian SMEs, Tesis. Australia (AU): Southern Cross University, Lismore.

27. Suryana. 2003. Kewirausahaan, Pedoman Praktis, Kiat dan Proses Menunju Sukses, Edisi Revisi, Jakarta: Salemba Empat.

28. Tobing, Sondang, Yohanna L. \& Rachma Fitriati. 2009. Pengaruh Organisasi Pembelajar Terhadap Kompetensi Pegawai Bank. Bisnis \& Birokrasi, Jurnal Ilmu Administrasi dan Organisasi, Jan-Apr 2009, pp. 25-35 Vol. 16 Nomor 1 ISSN 0854-3844.

29. Tunjungsari, Peni. 2011. Pengaruh Stress Kerja Terhadap Kepuasan Kerja Karyawan Pada Kantor Pusat PT. Pos Indonesia (Persero) Bandung. Universitas Komputer Indonesia. Vol. 1 No. 1, Maret 2011. 
30. United Nations. 2010. Creative Economy Report 2010. Creative Economy: A Feasible Development Option. Collaborative Effort Led by United Nations Conference on Trade and Development (UNCTAD) and United Nation Development Programe (UNDP) Special Unit for South-South Cooperation. (http://www.unctad.org/creative-economy, Diunduh 28 Oktober 2017).

31. Voss, G.B. \& Voss Z.G., 2000. Strategic Orientation And Firm Performance In an Artistic Enviroment. Journal of Marketing. January, pp. 67-83.

32. Widjaja, A.W. 2006. Administrasi Kepegawaian. Jakarta: Rajawali

33. Zimmerer, W.T. 2008. Essentials of Entrepreneurship and Small Business Management. Third Edition. New York: Prentice-Hall. 